\title{
Multi-Fuel Fuel Processor and PEM Fuel Cell System for Vehicles
}

\author{
Brian J. Bowers, Jian L. Zhao, Michael Ruffo, Druva Dattatraya, Rafey Khan, Pierre-Francois \\ Quet, Virginie Sweetland, Eric Darby, Yanlong Shi, Yakov Dorfman, Nathan Dushman, \\ Antonino Toro, lacopo Alberti, Amedeo Conti
}

Nuvera Fuel Cells, Inc.

\author{
Jean-Christophe Beziat, Fabien Boudjemaa
}

Renault

Copyright @ 2007 SAE International

\begin{abstract}
An ongoing program has made further technology advances in onboard fuel processors for use with PEM fuel cells. These systems are being explored as an option for reducing vehicle $\mathrm{CO}_{2}$ emissions and for other benefits such as fuel-flexibility that would allow vehicles to operate on a range of bio-fuels, conventional fuels, and synthetic fuels to support diversification and/or "greening" of the fuel supply.
\end{abstract}

As presented at the 2006 SAE World Congress ${ }^{1}$, Renault and Nuvera Fuel Cells previously developed fuel processor technology that achieved automotive size (80 liters) and power (1.4 g/s of hydrogen production) and reduced the startup time from more than 60 minutes to between 1.4 and 3.7 minutes to have $\mathrm{CO}<100 \mathrm{ppm}$. This paper presents an overview of the multi-fuel fuel cell power plant along with advances in the fuel processing system (FPS) technology and the testing results obtained since those reported in 2006.

The latest generation of this technology has made advances by improving the hydrogen efficiency to more than $80 \%$ over the entire operating range ( 33 to $215 \mathrm{~kW}_{\text {th }}$ fuel input) while keeping $\mathrm{CO}$ below the $100 \mathrm{ppm}$ target, lowering the pressure drop to improve system efficiency, and simplifying the balance of plant including eliminating the need for unreliable steam components. This fuel processor system also replaced laboratory air supply components with a low pressure drop automotive-style air supply system that successfully controlled the split of flow from the main compressor into three parallel branches for the ATR, Prox, and TGC.

In addition, an automotive fuel processor was tested with an automotive fuel cell stack and produced electricity from a broad range of fuels including ethanol, gasoline, and diesel. As an extreme demonstration of the fuelflexibility, data is presented for a real-time switch from ethanol to diesel while the fuel cell continues to produce electric power. This demonstrates a switch from a biofuel to a difficult conventional fuel and also shows the use of a spark ignition fuel and a compression ignition fuel in the same hardware.

\section{INTRODUCTION}

To reduce greenhouse gas emissions, automakers are actively pursuing alternative propulsion systems. Following the historic Kyoto Protocol ${ }^{2}$, European automakers voluntarily committed to reduce $\mathrm{CO}_{2}$ emissions by $25 \%$ from 1995 levels by 2008 with the possibility of even further reductions in $2012^{3}$. To achieve these large reductions, improvements to current engine technology are being pursued along with new power plant technologies. Fuel Cell Vehicles offer an exciting option by producing electric power through a reaction that combines hydrogen and oxygen to make water. However, hydrogen storage onboard vehicles and construction of an expensive hydrogen fueling infrastructure remain as challenges today. In addition, greenhouse gas emissions from the production of hydrogen must be considered since most hydrogen is currently produced from non-renewable sources. While these issues are being worked on, Renault is pursuing a fuel cell vehicle with a fuel processor that produces hydrogen onboard the vehicle from fuels such as ethanol, gasoline, and diesel. This technology also offers a way to diversify the fuel supply based on regional needs using a range of fuels including bio-fuels, conventional fuels, and synthetic fuels.

Renault and Nuvera are currently pursuing onboard fuel processor technology in a three and a half year program ${ }^{4}$ with the goal of achieving the technical requirements for a commercial vehicle system at the end of Phase 4 . The program is currently near the end of Phase 3, which builds upon the success of Phases 1,2 and 3 as reported in previous papers ${ }^{1,5,6,7,8}$. 


\section{GASOLINE FUEL CELL VEHICLE GOALS}

While gasoline Fuel Cell Vehicles (FCV's) hold promise for reduced emissions, they face challenges that require development of new component technologies. Today, automotive consumers are accustomed to the many desirable features of conventional vehicles and would be reluctant to accept any decrease in performance. Therefore, FCV's seek to improve emissions but should otherwise have specifications that are the same or better than Internal Combustion Engine vehicles. With this consideration, we should have a vehicle with nearly instantaneous capability to begin driving and the possibility to make power transients as often as required. While these startup and transient requirements are challenging for Gasoline Fuel Cell power plants (which include a fuel processor, fuel cell stack, air compressor, and other components) Renault and Nuvera are working to address the requirements needed to successfully introduce these vehicles to the market.

A SCENIC II gasoline fuel cell vehicle model has been developed to predict vehicle performance. Renault's target for a commercial onboard fuel processor / fuel cell vehicle is a well-to-wheels $\mathrm{CO}_{2}$ emissions of $100 \mathrm{~g}$ of $\mathrm{CO}_{2} / \mathrm{km}$ with $80 \mathrm{~g}$ of $\mathrm{CO}_{2} / \mathrm{km}$ for the onboard tank-towheels portion. Correlating these emissions with the properties of the primary design fuel (gasoline), the fuel consumption should be around 3.2 liters $/ 100 \mathrm{~km}$. To reach this value, a high efficiency power plant is needed.

\section{POWER PLANT GOALS}

From the above vehicle goals, Renault has defined the main power plant features: a net electric power of $70 \mathrm{~kW}$, associated with a target efficiency of $40 \%$, leading to a fuel processor able to convert roughly $200 \mathrm{~kW}_{\text {th }}$ of fuel input. To achieve these goals, a road-map was built, considering several power plant generations. Table 1 summarizes the major power plant objectives for 2006.

Table 1. Renault Power Plant Objectives for 2006

\begin{tabular}{|l|l|}
\hline Characteristic & Objective \\
\hline Target Fuel for Design & Euro 2010 Gasoline \\
\hline Other fuels & Ethanol, Diesel, \& Methanol \\
\hline Electric Power & $70 \mathrm{kWe}$ \\
\hline Efficiency & $\begin{array}{l}30 \% \text { @ mid load } \\
35 \% \text { @ full load }\end{array}$ \\
\hline Volume & 280 liters \\
\hline Mass & $235 \mathrm{~kg}$ \\
\hline Startup time & $2 \mathrm{~min}$ \\
\hline Water requirements & No water addition to the vehicle \\
\hline Transient (idle to 90\%) & 7 seconds \\
\hline
\end{tabular}

The test-bench systems of the current program must pave the way towards a vehicle-integrated system, especially in terms of size, weight, and transient response. In addition to lowering $\mathrm{CO}_{2}$, it is expected that the system will significantly reduce pollutant emissions such as CO, NOx, and hydrocarbons to be well below upcoming regulations. The power plant is also expected to be independent from water addition. Although the development work is carried out using gasoline as the design fuel, a system designed for gasoline and properly operated can also reform other fuels of interest including ethanol, diesel, and methanol.

\section{FUEL PROCESSOR SYSTEM}

\section{FUEL PROCESSOR SYSTEM GOALS}

Table 2 summarizes the goals for the Phase $3 \mathrm{~A}$ fuel processor, which is the 2005 generation system that was updated during 2006 and was testing at the time of the writing of this paper. Many targets, such as the volume remain the same as Phase 2. However, Phase 3A continues to advance the technology with a faster startup time target on the pathway toward the 30 second Phase 4 objective. Phase $3 \mathrm{~A}$ also has a larger hydrogen output $(1.4 \mathrm{~g} / \mathrm{s}$ vs. $1.3 \mathrm{~g} / \mathrm{s}$ for Phase 2) and longer durability targets with evaluations of both steady state and cyclic operation. (equivalent steady state run time of 3000 hours vs. 2000 hours for Phase 2).

In addition to the new Phase $3 \mathrm{~A}$ goals for startup, hydrogen output, and durability, the other fuel processor system goals remain similar to Phase 2. To fit under the vehicle, the fuel processor reactor is sized for 80 liters with a height of $23 \mathrm{~cm}$ to contain its catalysts and heat exchangers. The system design focuses on desulfurized gasoline, but the ATR technology is capable of processing other fuels including ethanol, diesel, methanol, and natural gas. The steady state $\mathrm{CO}$ target is $100 \mathrm{ppm}$, which assumes continuing improvements to PEM technology, but the CO can be lowered with a small tradeoff in the hydrogen efficiency.

Table 2. Phase 3A Fuel Processor Design Goals for 2006

\begin{tabular}{|c|c|c|}
\hline Characteristic & Design Goal & Comments \\
\hline Startup time & $\begin{array}{l}4 \min \\
\left(1.4-3.7 \min ^{1}\right. \\
\left.\text { already shown }{ }^{1}\right)\end{array}$ & $\begin{array}{l}<100 \mathrm{ppm} \mathrm{CO} ;<1 \mathrm{~min} \\
\text { needed in future }\end{array}$ \\
\hline $\begin{array}{l}\text { Maximum hydrogen in } \\
\text { reformate }\end{array}$ & $1.4 \mathrm{gram} / \mathrm{sec}$ & $\begin{array}{l}\sim 168 \mathrm{~kW}_{\text {th }} \text { based on } \\
\text { LHV }\end{array}$ \\
\hline Durability & $\begin{array}{l}3000 \text { hours steady } \\
500 \text { hours cycle }\end{array}$ & $\begin{array}{l}\text { Long term goal of } 5000 \\
\text { hours on driving cycle }\end{array}$ \\
\hline $\begin{array}{l}\text { Fuel Processor Volume* } \\
\text { *without balance of } \\
\text { plant components or } \\
\text { plumbing }\end{array}$ & $\leq 80$ Liters & $\begin{array}{l}\text { Includes everything } \\
\text { between cold feed } \\
\text { streams and } 100^{\circ} \mathrm{C} \\
\text { fuel-cell-quality } \\
\text { reformate outlet stream. }\end{array}$ \\
\hline Height & $<23 \mathrm{~cm}$ & $\begin{array}{l}\text { "Flat" aspect ratio for } \\
\text { vehicle installation }\end{array}$ \\
\hline Catalysts & Non-pellet-catalyst & Minimize volume \\
\hline Fuel Type & $\begin{array}{l}\text { Desulfurized Euro } \\
2010 \text { Gasoline }\end{array}$ & $\begin{array}{l}<2 \text { ppm-weight sulfur. } \\
\text { External desulfurization. } \\
\text { Other fuels tested. }\end{array}$ \\
\hline $\begin{array}{l}\text { Full power hydrogen } \\
\text { Efficiency }\end{array}$ & $\geq 77 \%$ & LHV $\mathrm{H}_{2} /$ LHV ATR fuel \\
\hline Residual fuel (as $\left.\mathrm{CH}_{4}\right)$ & $<1 \%$ (dry) & At PrOx exit \\
\hline $\begin{array}{l}\text { Assumed } \mathrm{FC} \mathrm{H} \mathrm{H}_{2} \\
\text { utilization }\end{array}$ & $80 \%$ & $\begin{array}{l}\text { At peak power } \\
\text { To design TGC burner }\end{array}$ \\
\hline $\begin{array}{l}\text { CO - steady state } \\
\text { CO - transient }\end{array}$ & $\begin{array}{l}\leq 100 \text { ppmv (dry) } \\
<1000 \text { ppmv (dry) }\end{array}$ & At $\mathrm{PrOx}$ exit \\
\hline Reformate pressure & 3 bar & At PrOx exit \\
\hline Pressure loss & $\leq 0.7$ bar & ATR air inlet - PrOx exit \\
\hline
\end{tabular}




\section{FUEL PROCESSOR DESIGN}

As described in the 2006 SAE paper ${ }^{1}$, the Phase 3A fuel processor was designed to meet the Table 2 targets, which include performance objectives such as hydrogen output as well as packaging objectives. To summarize, the automotive fuel processor is designed to fit in an under-floor vehicle compartment and is based on an autothermal reforming (ATR) process. To produce hydrogen with low $C O$ for use in a fuel cell, the fuel processor contains five catalyst zones as listed below and shown in Figure 1:

1. Autothermal reforming (ATR) catalyst

2. High Temperature water gas Shift (HTS) catalyst

3. Low Temperature water gas Shift (LTS) catalyst

4. Preferential Oxidation (PrOx) of CO catalyst

5. Tail Gas Combustion (TGC) catalyst

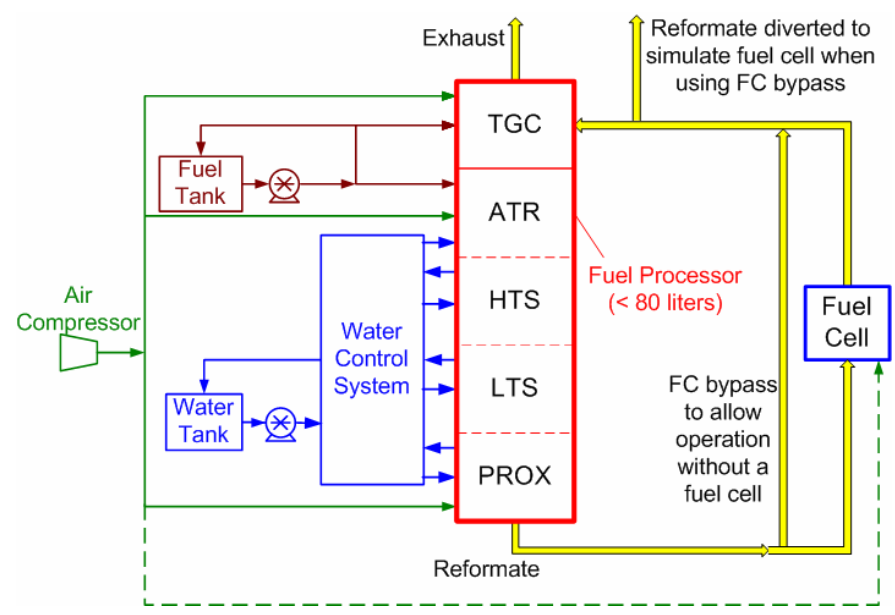

Figure 1. Fuel Processor Test System Layout

As reported previously, this automotive fuel processor design has evolved in several steps throughout Phases 1,2 , and 3 of this program ${ }^{1}$. The first major design step occurred during and prior to Phase 1, where traditional industrial reforming technologies using pellet-based catalysts were replaced by substrate-based catalysts and custom heat exchangers in order to achieve a volume reduction of more than 10 times (80 liters vs. $>800$ liters). During Phase 2, some of the industrial style balance of plant (BOP) controls components were replaced with automotive-style components such as injectors for fuel, water, and steam.

Phase $3 \mathrm{~A}$ has continued this design evolution in terms of performance, packaging, and controls. First, the Phase 3A fuel processor increased the overall system power from $200 \mathrm{~kW}_{\text {th }}$ to $215 \mathrm{~kW}_{\text {th }}$ of fuel input (LHV basis) and from 1.3 to $1.4 \mathrm{~g} / \mathrm{s}$ of hydrogen output. The first FPS $3 \mathrm{~A}$ (FPS 3A unit 1 shown in Figure 2) demonstrated this higher power and higher power density operation ${ }^{1}$. During 2006, two design iterations produced FPS 3A unit 3 (Figure 3), which was designed to lower the water consumption (mainly to reduce the radiator load needed for water recovery) and to further reduce the pressure drop (in order to reduce compressor power and improve system efficiency). In addition, the FPS $3 A$ unit 3 improved the BOP by removing unreliable steam injectors and flow sensors (upper left in Figure 2), replacing low-durability water injectors (upper right and middle in Figure 2), and replacing laboratory air mass flow controllers with low-pressure drop automotive air valves and sensors (top of Figure 3). All of this was done within the target "flat" aspect ratio package designed to fit under the vehicle floor.

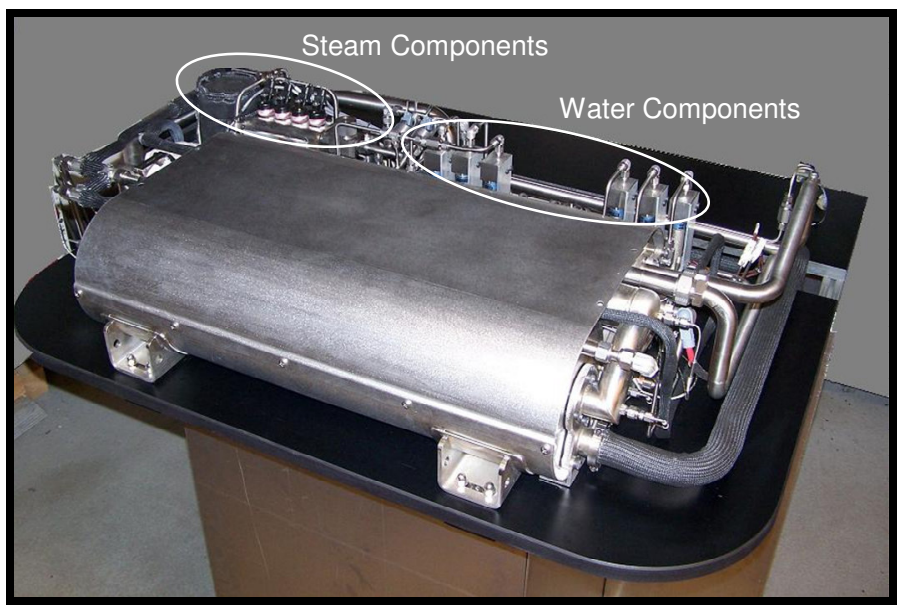

Figure 2. FPS 3 A unit 1 fuel processor on test stand - 2005

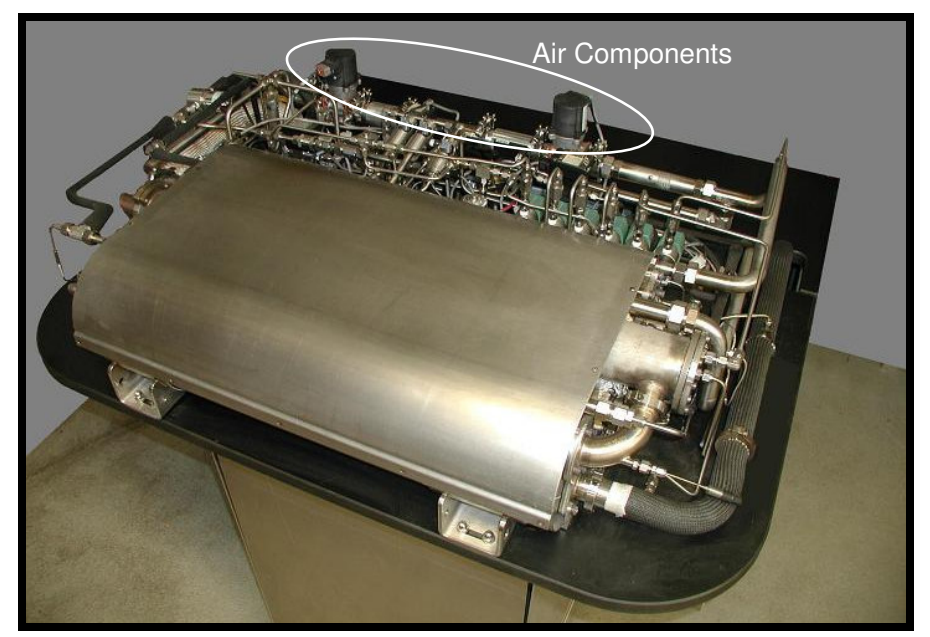

Figure 3. FPS $3 A$ unit 3 fuel processor on test stand -2006 . Note removal of low-durability steam components, upgrade of water components, and addition of low pressure drop air system.

\section{FUEL PROCESSOR TEST RESULTS}

To validate the new design and confirm its performance, FPS $3 A$ unit 3 was tested on gasoline under steady state conditions covering a 6.5 to 1 turndown range (215 to 33 $\mathrm{kW}_{\text {th }}$ of fuel input). During these tests, the gas composition was measured through both gas chromatograph and continuous IR-type analyzers. This data allows the hydrogen efficiency, hydrogen concentration, and $\mathrm{CO}$ at the exit of the Prox to be compared against the targets. In addition, an automated 
system allowed measurements of the gas concentrations throughout the fuel processor to check the design and performance of individual catalyst beds.

One of the primary purposes for the design iterations between FPS $3 A$ unit 1 and unit 3 was to reduce the pressure drop of the system. To minimize the power required by the air compressor, a target of 0.7 bar or less was set for the pressure drop between the ATR inlet and the Prox exit. By improving the open area of the catalysts, eliminating unnecessary restrictions, and redesigning mixing zones, Figure 4 shows that a 0.6 bar pressure drop at full power $\left(215 \mathrm{~kW}_{\text {th }}\right)$ was achieved. At $40 \mathrm{~kW}_{\text {th }}$ the pressure drop was only 0.07 bar. This lower pressure drop design allows the use of an onboard air compressor while minimizing the power required for the compressor and thus improve the net system efficiency.

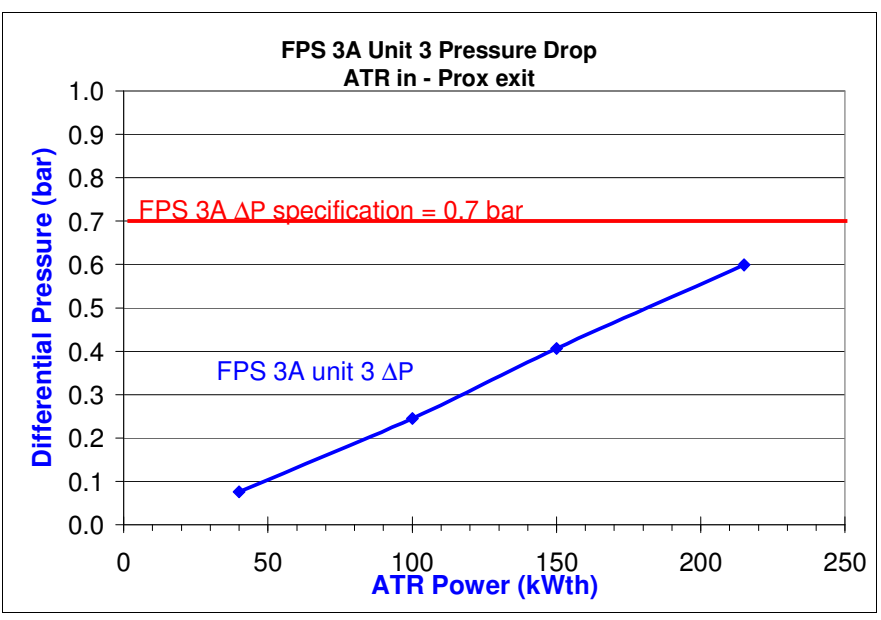

Figure 4. Pressure drop of Phase 3A unit 1 fuel processor

In addition to lowering the pressure drop of the fuel processor reactors, low pressure drop air controls components are also desired. Therefore, three air branches (ATR, Prox, TGC) were upgraded from laboratory air mass flow controllers to use low pressure drop air valves and air sensors. As shown in Figure 1, the system design has one main air compressor to supply all the air for both the fuel processor and fuel cell. Since this testing focused only on the fuel processor system, the air compressor was simulated with a single mass flow controller to feed air to these three fuel processor branches. The low pressure drop design of these three parallel branches causes a high degree of cross-sensitivity between the flows, which must be handled by the control system. In addition, the air control system must compensate for changes in the relative pressures between the reactors that are a function of the operating power level as shown in Figure 4. Therefore, a significant effort was put into the design of the controls for these parallel low-pressure drop air branches. The result was a successfully tuned air supply system that keeps the common air supply manifold pressure as low as possible to reduce compressor load while still allowing the control over the full operation range from startup to the full power condition of $215 \mathrm{~kW}_{\text {th }}$.
All of the following validation testing plots for the FPS $3 \mathrm{~A}$ unit 3 were collected using the upgrades described above including the three parallel branches of low pressure drop air control components.

Figure 5 shows testing of the FPS $3 \mathrm{~A}$ unit 3 fuel processor at low power (33 $\mathrm{kW}_{\text {th }}$ gasoline input) with $82.7 \%$ hydrogen efficiency, $41.6 \%$ dry hydrogen concentration, and $33-57 \mathrm{ppm} \mathrm{CO}$ at the Prox exit. Note that the Prox reactor is excellent at the low power level with only a $0.4 \%$ drop in the hydrogen efficiency between the LTS exit and Prox exit. Also the control shows stable operation as the CO stays within 20 ppm over this 50 minute test.

Figure 6 shows testing of the FPS $3 A$ unit 3 fuel processor at $100 \mathrm{~kW}_{\text {th }}$ with $80.9 \%$ hydrogen efficiency, $41.0 \%$ dry hydrogen concentration, and $45-93$ ppm CO at the Prox exit.

Figure 7 shows testing of the FPS $3 A$ unit 3 fuel processor at $150 \mathrm{~kW}_{\text {th }}$ with $81.1 \%$ hydrogen efficiency, $41.1 \%$ dry hydrogen concentration, and $70-92$ ppm CO at the Prox exit.

Figure 8 shows testing of the FPS $3 A$ unit 3 fuel processor at the full power condition of $215 \mathrm{~kW}_{\text {th }}$. The system greatly exceeds the $77 \%$ hydrogen efficiency target with $81.7 \%$ hydrogen efficiency. This gives 1.46 $\mathrm{g} / \mathrm{s}$ of hydrogen output, which also exceeds the target of $1.40 \mathrm{~g} / \mathrm{s}$. The hydrogen efficiency drops $3.4 \%$ across the Prox, showing high selectivity for $\mathrm{CO}$ oxidation and a well designed reactor. The Prox $\mathrm{CO}$ is kept right at the 100 ppm target, ranging from 90 to 113 ppm with $40.1 \%$ dry hydrogen concentration.

Overall, the validation testing of FPS $3 \mathrm{~A}$ unit 3 shows that this fuel processor system successfully operates over the power range of 33 to $215 \mathrm{~kW}_{\text {th }}$ while controlling $\mathrm{CO}$ below the $100 \mathrm{ppm}$ target and hydrogen efficiency above the $77 \%$ target. This performance was achieved while maintaining a compact under-vehicle package and incorporating improvements over FPS $3 A$ unit 1 including a lower pressure drop, 15\% lower water consumption, removal of low-durability steam and water components, and a low-pressure-drop air supply system that feeds three air branches in parallel. Table 3 shows that FPS $3 A$ unit 3 with these improved features also improved the hydrogen efficiency approximately $1-5 \%$ over the operating range to a level of $80.9 \%$ to $82.7 \%$. 


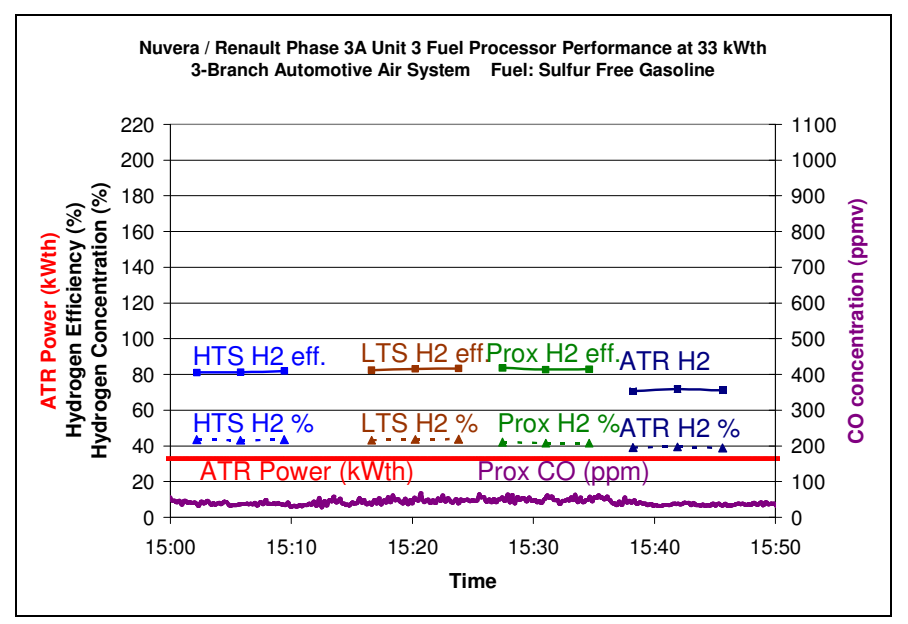

Figure 5. Phase $3 \mathrm{~A}$ unit 1 fuel processor validation test at $33 \mathrm{~kW}_{\text {th }}$

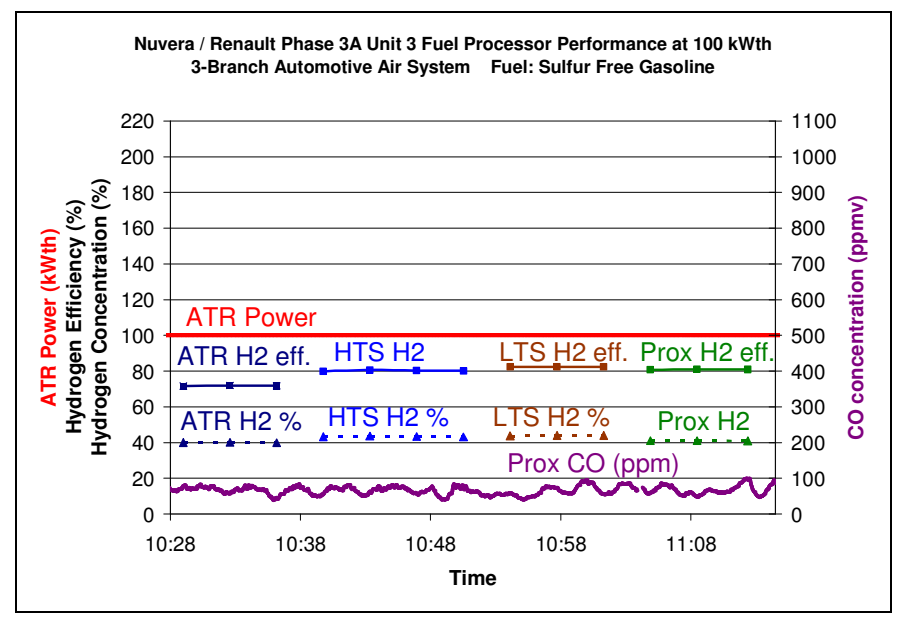

Figure 6. Phase $3 \mathrm{~A}$ unit 1 fuel processor validation test at $100 \mathrm{~kW}_{\mathrm{th}}$

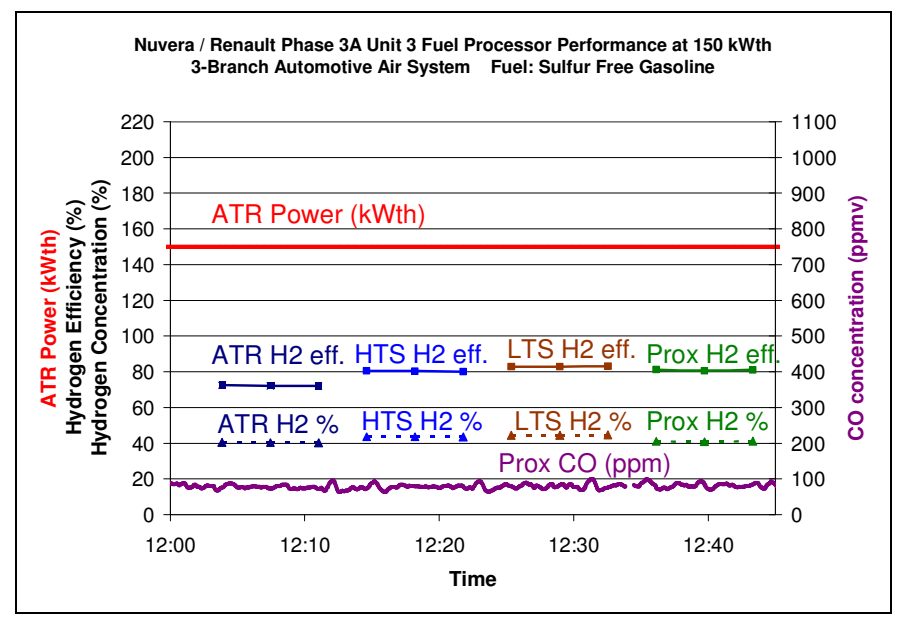

Figure 7. Phase $3 \mathrm{~A}$ unit 1 fuel processor validation test at $150 \mathrm{~kW}_{\text {th }}$

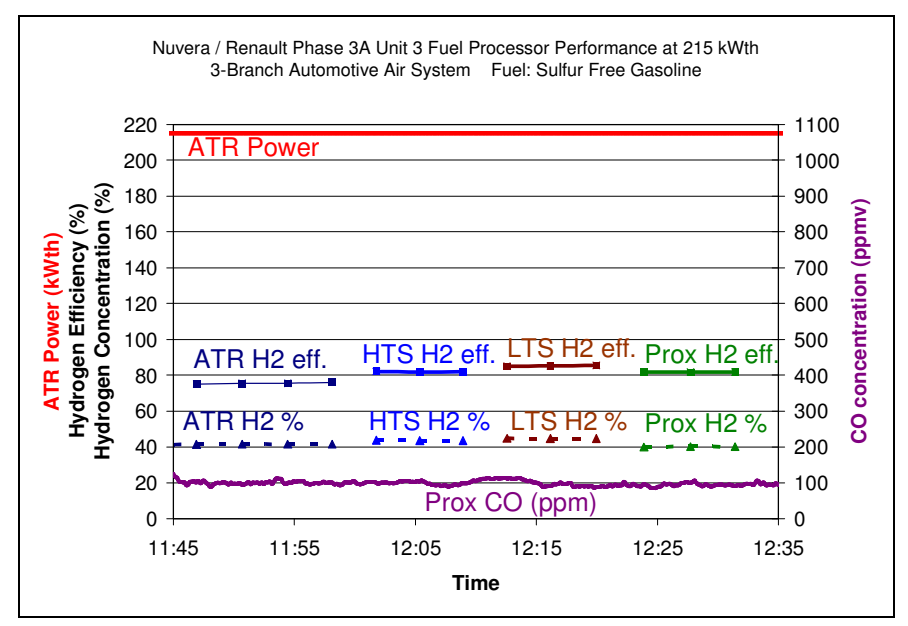

Figure 8. Phase $3 \mathrm{~A}$ unit 1 fuel processor validation test at $215 \mathrm{~kW}_{\text {th }}$

Table 3. Hydrogen efficiency of FPS $3 A$ unit 1 and FPS $3 A$ unit 3

\begin{tabular}{|c|lrrrrr|}
\cline { 3 - 7 } \multicolumn{2}{c|}{} & \multicolumn{4}{c|}{ Fuel Input Power $\left(\mathrm{kW}_{\text {th }}\right)$} \\
\cline { 3 - 7 } \multicolumn{2}{c|}{} & 33 & 100 & 150 & 215 \\
\hline Hydrogen & Target & $\geq 77.0$ & $\geq 77.0$ & $\geq 77.0$ & $\geq 77.0$ \\
Efficiency & Unit 1 & 81.0 & 80.0 & 78.5 & 77.0 \\
$(\%)$ & Unit 3 & 82.7 & 80.9 & 81.1 & 81.7 \\
\hline & Improvement & 1.7 & 0.9 & 2.6 & 4.7
\end{tabular}

\section{FUEL PROCESSOR - FUEL CELL INTEGRATION TEST RESULTS}

In addition to the advances made on the FPS 3 A unit 3 , the Phase 2 fuel processor (FPS 2.5) was tested with a fuel cell stack. The purpose of the testing was to show the integration of these components and demonstrate the production of electricity from a variety of fuels.

As reported previously ${ }^{8}$, FPS 2.5 has successfully reformed multiple fuels including gasoline, ethanol, and methanol. In addition, low-sulfur diesel fuel was recently tested as shown in Figure 9. This shows a wide range of fuels that can be reformed and gives the possibility of a fuel-flexible fuel cell engine.

As a first step toward a fuel-flexible engine, Figure 10 shows that FPS 2.5 was tested over the power range of 50 to $200 \mathrm{~kW}_{\text {th }}$ with real-time switches of fuel from gasoline to diesel at four power levels. This test successfully showed the control of $\mathrm{CO}$ during the fuel changes while maintaining hydrogen efficiencies of about $80 \%(77.5-82.0 \%)$ In addition, tests of the reformate quality showed low levels of contaminants and opened the possibility of a real time fuel switch while producing power from a fuel cell. 


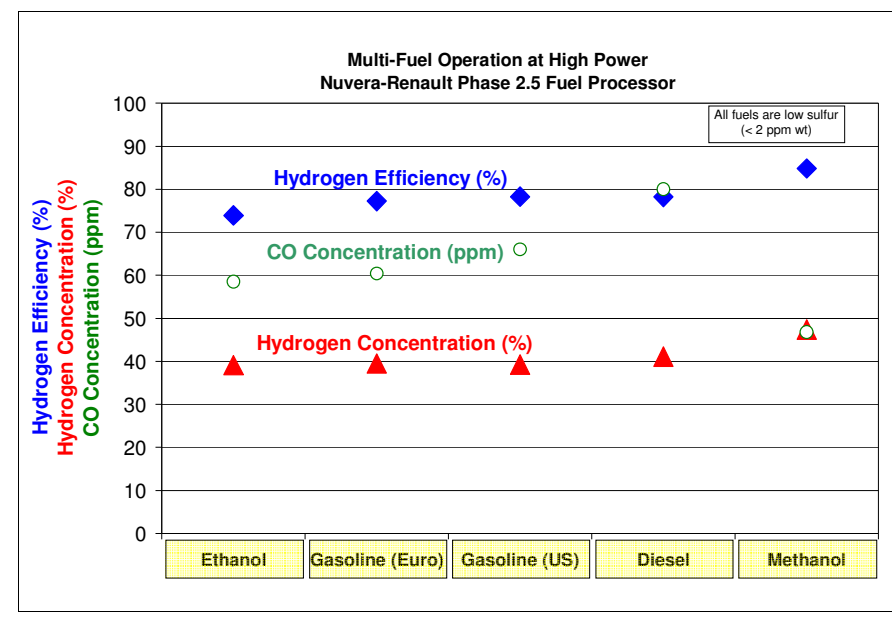

Figure 9. FPS 2.5 operation on multi-fuels

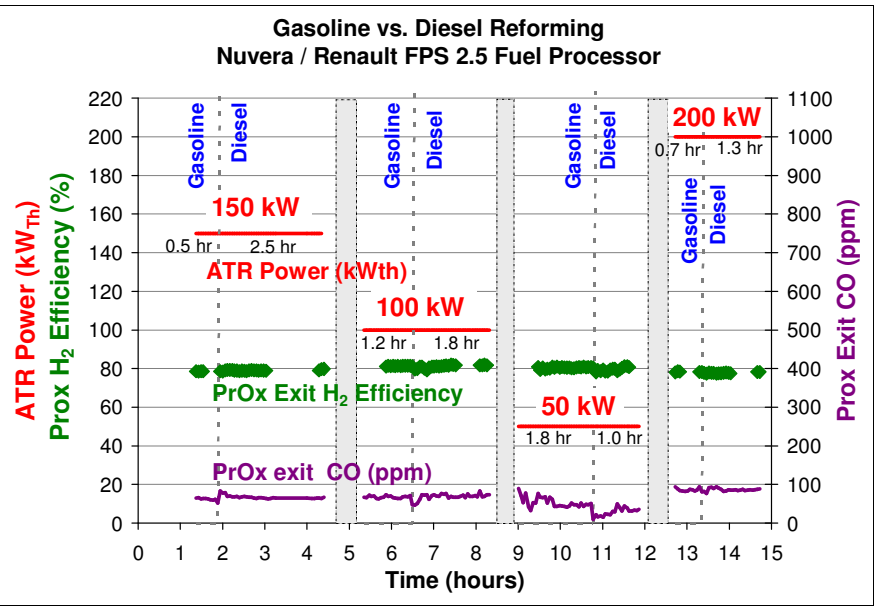

Figure 10. Real-time switch of fuel from gasoline to diesel on FPS 2.5

To show the production of power from a fuel cell using multiple fuels, the FPS 2.5 was connected with a subscale Andromeda ${ }^{\mathrm{TM}}$ automotive fuel cell stack as illustrated in Figure 11. This testing produced the polarization curve shown in Figure 12. During the testing, FPS 2.5 produced hydrogen reformate from ethanol (E95), gasoline, and diesel fuel with low CO and the fuel cell successfully converted the reformate into electricity up to a maximum of about $15 \mathrm{kWe}$. Since this fuel cell design has been successfully used in hydrogen vehicles ${ }^{9}$, the reformate results were compared to hydrogen operation. The polarization curve shows the fuel cell is able to operate on the reformate produced by the FPS 2.5 fuel processor without a significant decrease in voltage.

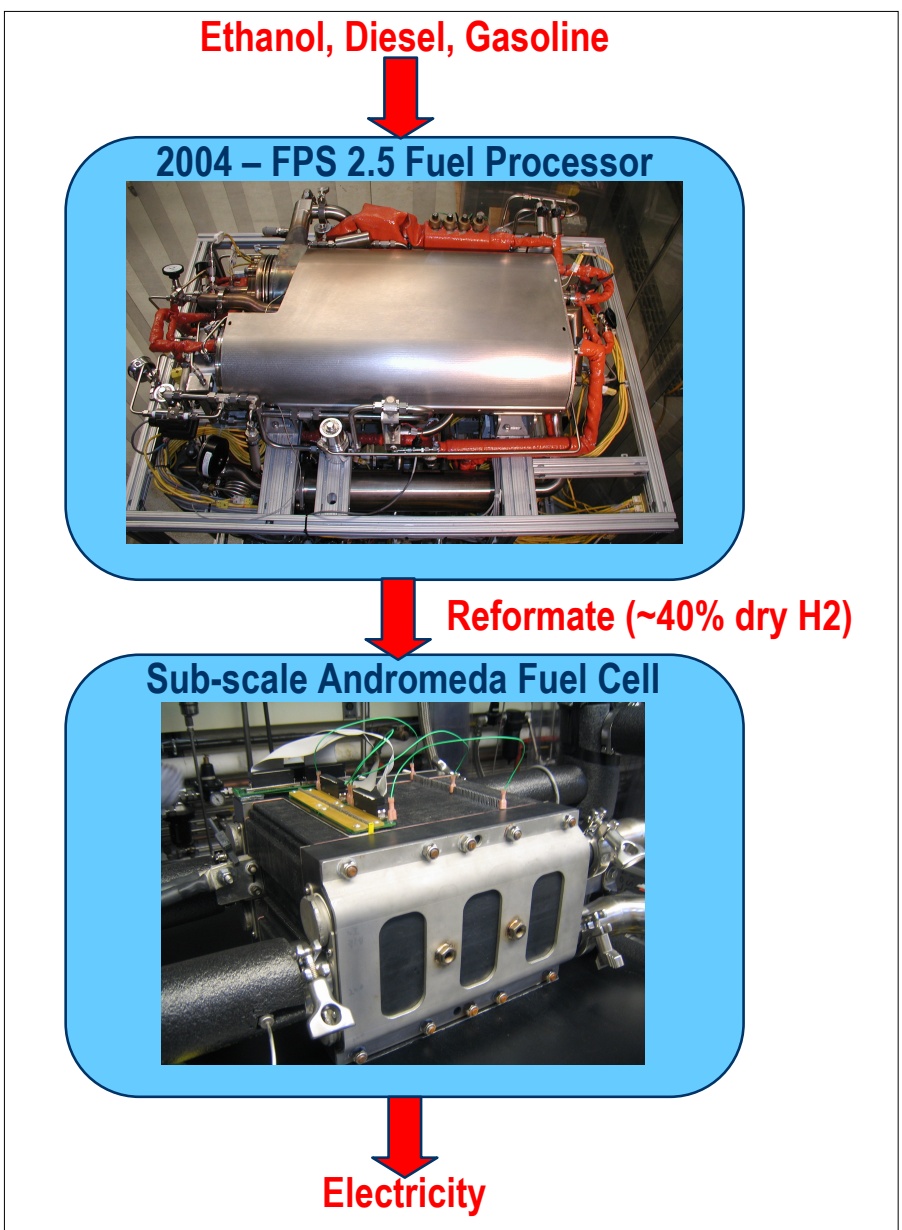

Figure 11. FPS 2.5 Fuel Processor and Andromeda Fuel Cell used to demonstrate fuel-flexible production of electricity

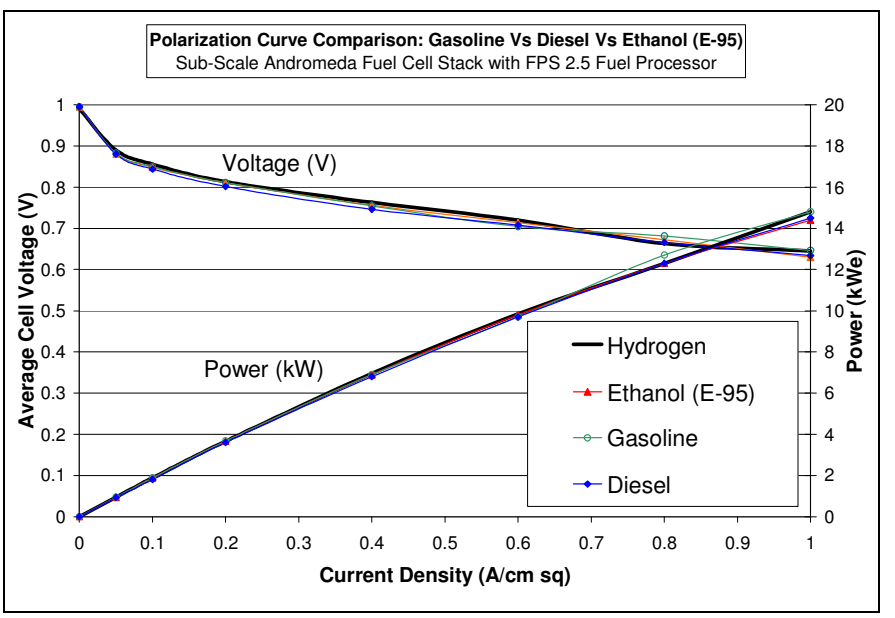

Figure 12. Andromeda Fuel Cell polarization curve on hydrogen and on three liquid fuels reformed by FPS 2.5 
After the steady state testing of Figure 12, the knowledge gained from the real-time fuel switches of Figure 10 was used to facilitate a rather extreme demonstration of fuel flexibility. Figure 13 shows that FPS 2.5 successfully operated on ethanol (E95) and produced hydrogen reformate with about $30 \mathrm{ppm}$ of $\mathrm{CO}$ that was sent to the fuel cell to produce $5.3 \mathrm{kWe}$. Without stopping, the fuel supply was switched to diesel fuel and, after a brief dip in reformate flow, the power returned to $5.3 \mathrm{kWe}$ in under 10 seconds. During this transition, the fuel processor control computer automatically updated the operating maps for the new fuel and the CO dropped to $10 \mathrm{ppm}$. This real-time switch shows the use of a spark-ignition fuel and a compression ignition fuel, as well as a bio-fuel and a conventional fuel in the same engine. While it is unlikely that such a non-stop fuel switch would be needed on a vehicle, this demonstration opens up the possibility of a fuel-flexible vehicle capable of operating on the local fuel of choice in markets around the world.

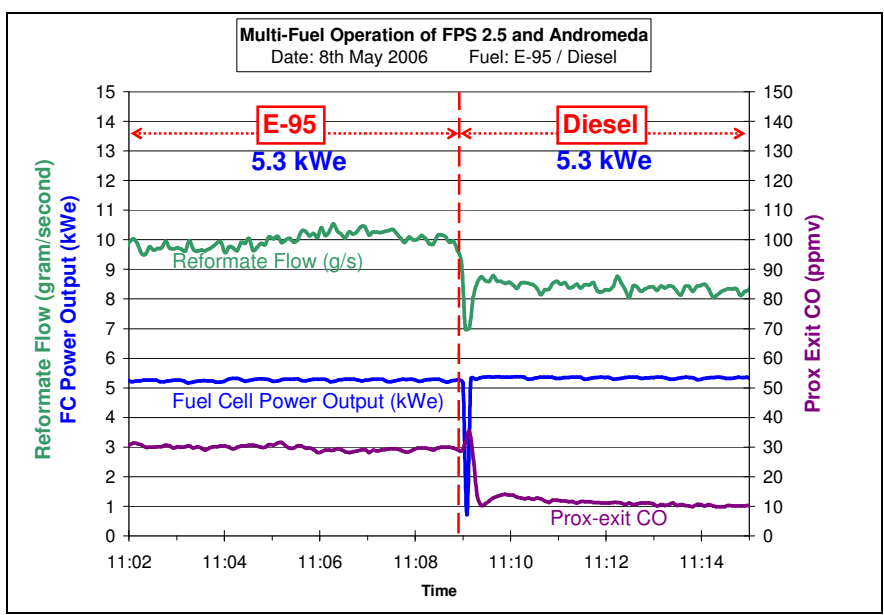

Figure 13. Real-time fuel switch while producing electricity from the fuel cell

\section{CONCLUSION}

After the historic Kyoto Protocol, European automakers voluntarily agreed to reduce vehicle $\mathrm{CO}_{2}$ emissions. This commitment has promoted numerous activities to develop cleaner and more efficient vehicles through technologies such as fuel cells. Renault and Nuvera are pursuing a three and a half year program to develop a multi-fuel onboard fuel processor that can provide hydrogen to a PEM fuel cell on the vehicle. This system shows promise to improve overall well-to-wheels $\mathrm{CO}_{2}$ emissions and reduce pollutant emissions below upcoming standards. The program is now in Phase 3 and will continue development in Phase 4 through 2007.

The latest generation of fuel processor (FPS $3 A$ unit 3 ) is packaged with reactors and BOP controls components in an under-vehicle configuration and has been validated over a 6.5 to 1 turndown range of 33 to $215 \mathrm{~kW}_{\text {th }}$ of fuel input. During these tests, the $\mathrm{CO}$ was controlled under the $100 \mathrm{ppm}$ target with hydrogen efficiencies of $81-83 \%$. This is well above the $77 \%$ target and a $1-5 \%$ improvement over FPS $3 \mathrm{~A}$ unit 1 as described in the previous SAE paper. In addition, to the improved efficiency, FPS $3 \mathrm{~A}$ unit 3 lowered the pressure drop under the 0.7 bar target to 0.6 bar at full power and lowered the molar steam to carbon ratio $(\mathrm{S} / \mathrm{C})$ by more than $15 \%$. All of this testing was done using improvements to the BOP including removal of lowdurability steam and water components and the successfully installed low pressure drop automotive-style air supply system that splits the flow from the main compressor into three parallel branches.

In parallel to the Phase $3 \mathrm{~A}$ work, the Phase 2 fuel processor (FPS 2.5) was successfully tested on a variety of fuels while integrated with a fuel cell. FPS 2.5 produced hydrogen reformate from ethanol (E95), gasoline, and diesel fuel and the fuel cell successfully converted this reformate to electricity without a significant decrease in voltage as compared to pure hydrogen operation. In addition, FPS 2.5 facilitated an extreme demonstration of fuel flexibility with a real-time switch from ethanol to diesel without stopping the power production from the fuel cell. This shows the use of a spark-ignition fuel and a compression ignition fuel as well as a bio-fuel and a difficult conventional fuel in the same engine. This demonstration also opens up the possibility of a fuel-flexible vehicle capable of operating on the local fuel of choice in markets around the world.

Overall, the Renault and Nuvera fuel processor development has been very successful at achieving the design goals of each phase. Ongoing work through Phases 3 and 4 will continue this work and improve performance toward the ultimate targets needed for a production multi-fuel fuel cell vehicle.

\section{REFERENCES}

1. Bowers, Zhao, Ruffo, Khan, Sweetland, Beziat, and Boudjemaa. Advanced Onboard Fuel Processor for PEM Fuel Cell Vehicles. 2006 SAE World Congress. 2006-01-0216.

2. Kyoto Protocol to the United Nations Framework Convention on Climate Change. Adopted at the third session of the Conference of the Parties to the UNFCCC in Kyoto, Japan, on 11 December 1997.

3. European Automobile Manufactures Association (ACEA). The European Automobile Manufacturers commit to substantial $\mathrm{CO}_{2}$ emission reductions from new passenger cars. http://www.acea.be/ACEA/ 290798.html. Press Release. 29 July 1998.

4. Renault and Nuvera Strengthen Ties for Joint Fuel Cell Research Venture. Press Release. May 19 2004. www.nuvera.com

5. Bowers, Boudjemaa, Zhao, Dattatraya and Ruffo. Performance of an Onboard Fuel Processor for PEM Fuel Cell Vehicles. 2005 SAE World Congress. 2005-01-0008.

6. Bowers, Zhao, Ruffo, Khan, Dattatraya, Dushman, Beziat, and Boudjemaa. Onboard Fuel Processor for PEM Fuel Cell Vehicles. Presented at the 2005 European Hydrogen Energy Conference, Nov 2005. 
7. Bowers, Boudjemaa, Zhao, Dattatraya and Rizzo. Development of an Onboard Fuel Processor for PEM Fuel Cell Vehicles. 2004 SAE World Congress. 2004-01-1473

8. Bowers, Zhao, Ruffo, Khan, Dattatraya, Dushman, Beziat, and Boudjemaa. Onboard Fuel Processor for PEM Fuel Cell Vehicles. Presented at the 2005 European Hydrogen Energy Conference, Nov 2005. Publication in progress in a special edition of the International Journal of Hydrogen Energy

9. Mitchell and Toro. Advanced Fuel Cell Development for Automotive Operation. 2006 SAE World Congress. 2006-01-0035
DEFINITIONS, ACRONYMS, ABBREVIATIONS

ATR: Autothermal Reforming

BOP: Balance of Plant

FPS: Fuel Processing System

HTS / LTS: High / Low Temperature water-gas Shift

$\mathbf{k W}_{\mathrm{e}}$ : kilowatts electric

$\mathbf{k W}_{\text {th }}$ : kilowatts thermal (based on LHV of fuel flow)

LHV: Lower Heating Value

Prox: Preferential Oxidation

S/C: Molar steam to carbon ratio

TGC: Tail Gas Combustor 